\title{
SISTEM PENDUKUNG KEPUTUSAN PEMILIHAN PROGRAM STUDI DENGAN METODE SAW DAN AHP
}

\author{
Erikson Marbun ${ }^{1}$, Seng Hansun ${ }^{2}$ \\ 1erikson.marbun@student.umn.ac.id, ${ }^{2}$ hansun@umn.ac.id \\ 1,2Program Studi Informatika, Fakultas Teknik dan Informatika, Universitas Multimedia
}

\begin{abstract}
Abstrak
Penerimaan mahasiswa pada Universitas Multimedia Nusantara (UMN) terbagi menjadi jalur akademik, beasiswa, dan tes regular. Tolak ukur yang digunakan untuk menerima calon mahasiswa melewati jalur akademik masih melihat lima nilai akademik dengan minimal nilai 70 . terdapat kasus dimana minimal nilai menurun bergantung pada nilai KKM (Kriteria Ketuntasan Minimal) dari asal sekolah calon mahasiswa tersebut. Proses mengganti jurusan di UMN dapat dilakukan dengan mendatangi divisi Student Support dan menjalani rangkaian tes bergantung program studi yang dipilihnya. Student Support Fakultas Teknik dan Informatika(FTI) tidak mempunyai data yang cukup untuk melakukan tes yang spesifik. Berdasarkan kedua masalah tersebut maka dibangun sebuah sistem pendukung keputusan 'FTI Recommendation' menggunakan metode AHP dan SAW. Metode AHP sebagai dasar penilaian calon mahasiswa, sedangkan metode SAW untuk meranking alternatif. serta nilai referensi pakar sebagai pengganti tolak ukur lama, yaitu nilai 70 atau sesuai dengan KKM asal sekolah calon mahasiswa. Sistem pendukung keputusan yang dibangun menghasilkan tingkat kepuasan sebesar $77,22 \%$.
\end{abstract}

Kata kunci: AHP, program studi, FTI, SAW, sistem pendukung keputusan

\begin{abstract}
Admission to Multimedia Nusantara University (UMN) is divided into academic paths, scholarships and regular tests. The benchmarks used to accept prospective students through the academic track still see five academic grades with a minimum value of 70 . There are cases where the minimum grade decreases depending on the KKM (Minimum Completeness Criteria) from the school of the prospective student. The process of changing majors at UMN can be done by going to the Student Support division and undergoing a series of tests depending on the chosen study program. The Student Support Faculty of Engineering and Informatics (FTI) does not have enough data to carry out specific tests. Based on these two problems, a decision support system 'FTI Recommendation' was built using the AHP and SAW methods. AHP method is the basis for evaluating prospective students, while the SAW method is for alternative ranking. and the expert reference value as a substitute for the old benchmark, which is 70 or in accordance with KKM from the prospective student's school. The decision support system built produces a satisfaction level of $77.22 \%$.
\end{abstract}

Keywords: AHP, decision support system, FTI, study program, SAW

\section{Pendahuluan}

Proses penerimaan mahasiswa yang melewati jalur akademik di Universitas Multimedia Nusantara (UMN) dilakukan dengan cara membandingkan nilai para pendaftar dengan suatu nilai tolak ukur. Nilai tolak ukur yang dimaksudkan adalah nilai 70 atau setara dengan nilai KKM (Kriteria Ketuntasan Minimal) dari sekolah pendaftar sebagai tolak ukur. Nilai mata pelajaran yang selalu dilihat ketika mendaftarkan diri melewati jalur akademik adalah nilai Bahasa Indonesia, Bahasa Inggris, Matematika, Fisika dan TIK atau Kewirausahaan. Selain dari nilai mata pelajaran, faktor lain yang dilihat adalah asal jurusan sekolah dan minat program studi yang akan dipilih.

Menurut hasil wawancara dengan Bapak Johanes T. Boro selaku Student Recruitment dan Adminission Manager pada divisi Marketing UMN, proses penerimaan melewati jalur akademik yang masih mengacu pada nilai standar yaitu nilai 70 atau dalam beberapa kasus tolak ukur nilai dapat menurun sesuai dengan Kriteria Ketuntasan Minimal (KKM) dari sekolah calon mahasiswa. Hal ini menyebabkan tidak adanya variasi mahasiswa atau monoton karena tolak ukur yang ditetapkan selalu sama setiap tahunnya.

Proses perpindahan jurusan (program studi) di Universitas Multimedia Nusantara dapat dilakukan dengan cara mengunjungi Student Support untuk mengikuti serangkaian tes. Syarat untuk melakukan perpindahan program studi adalah minimal Indeks Prestasi Kumulatif (IPK) 2, dan telah menempuh minimal dua semester selama proses kuliah. Rangkaian tes yang diberikan oleh Student Support selalu berdasarkan program studi pilihan mahasiswa yang ingin berpindah program studi. Selama Student 
Support memiliki mempunyai data yang cukup akan program studi yang dipilih maka Student Support dapat membantu proses perpindahan program studi agar mendapatkan pilihan yang terbaik.

Dari hasil wawancara dengan Bapak Hadyan Dhiozandi, M.Psi., Psikolog, Student Support tidak dapat membantu mahasiswa yang ingin berpindah jurusan ke program studi yang ada di Fakultas Teknik dan Informatika (FTI) UMN. Hal ini disebabkan karena pihak Student Support kekurangan data dalam penggalian bidang peminatan program studi Fakultas Teknik dan Informatika. Karena data yang kurang, Student Support tidak dapat memberikan hasil yang terbaik apabila ada mahasiswa yang ingin berpindah ke program studi yang berada pada Fakultas Teknik dan Informatika.

Dari permasalahan tersebut, akan dibuatkan sebuah solusi untuk mengatasi masalah yang ada. Solusi yang dapat mengatasi masalah tolak ukur yang sama setiap tahunnya dan pemilihan program studi yang berada di Fakultas Teknik dan Informatika. Solusi tersebut adalah sistem pendukung keputusan (SPK) untuk memilih program studi yang berada di Fakultas Teknik dan Informatika, yang menghitung nilai-nilai akademik, minat program studi dan jurusan saat sekolah. Dengan bobot kriteria yang diberikan oleh pakar, dan nilai tolak ukur baru yang diberikan oleh pakar sesuai dengan preferensi masing-masing pakar pada program studi tersebut.

Metode yang digunakan pada pembangunan sistem pendukung keputusan (SPK) ini adalah metode Analytical Hierarchy Process (AHP) dan Simple Additive Weighting (SAW). Metode Analytical Hierarchy Process (AHP) merupakan metode pemecahan masalah yang kompleks dalam situasi yang tidak terstruktur menjadi komponen-komponen yang lebih kecil. AHP akan menyusun komponenkomponen ini dalam suatu bentuk susunan hierarki, yang selanjutnya diberikan nilai-nilai numerik sebagai bentuk penilaian subjektif terhadap kepentingan yang diyakini terdapat pada setiap variabel. Terakhir, proses sintesis penilaian untuk menemukan variabel yang memiliki prioritas tertinggi yang mempengaruhi penyelesaian dari permasalahan tersebut akan dilakukan. Analytical Hierarchy Process (AHP) secara tidak langsung akan menggabungkan pertimbangan dan penilaian subyektif melalui langkah-langkah yang logis serta dipengaruhi imajinasi, pengalaman, dan pengetahuan dalam menyusun hierarki dari suatu bentuk permasalahan yang berdasarkan logika, intuisi dan juga pengalaman untuk menghasilkan suatu bentuk keputusan [1]. AHP memiliki beberapa kelebihan dibandingkan metode lain dalam proses mengambil keputusan. Salah satu keunggulannya adalah bahwa AHP dapat secara grafis digambarkan, sehingga semua pihak yang terlibat dalam proses pengambilan keputusan dapat dengan mudah memahaminya.

Metode Simple Additive Weighting (SAW) atau yang dikenal juga sebagai metode penjumlahan berbobot merupakan salah satu algoritma yang umum digunakan dalam pembuatan sistem pendukung keputusan. Pencarian penjumlahan berbobot dari rating kinerja pada setiap alternatif yang ada di kriteria merupakan konsep dasar SAW [2].

Dengan dibuatnya sistem pendukung keputusan untuk memilih program studi di Fakultas Teknik dan Informatika, diharapkan dapat membantu dan menyelesaikan permasalahan yang ada. Sebuah sistem pendukung keputusan untuk memilih program studi di Fakultas Teknik dan Informatika dengan tolak ukur nilai yang baru sehingga dapat mengatasi permasalahan nilai tolak ukur yang sama setiap tahunnya atau nilai tolak ukur yang menurun karena nilai KKM sekolah calon mahasiswa yang kurang dari nilai standar yang ada.

\section{Metode}

Sistem pendukung keputusan merupakan suatu program komputer yang dapat digunakan untuk menganalisis dan menyajikan data sehingga penggunanya dapat membuat keputusan dengan lebih mudah[3]. Sebagai sebuah aplikasi informasi, sistem pendukung keputusan dapat menyajikan informasi secara grafis [4].

Sofiah dan Septiana [5] menjelaskan sejumlah karakteristik yang dimiliki oleh sistem pendukung keputusan, diantaranya

a. Dapat memecahkan permasalahan dengan sifat semi terstruktur ataupun tidak terstruktur.

b. Mengombinasikan penggunaan berbagai model dan teknik analisis dengan teknik konvensional.

c. Dapat dioperasikan dengan mudah oleh orang awam yang tidak memiliki dasar kemampuan pengoperasian komputer yang tinggi.

d. Memiliki fleksibilitas dan kemampuan adaptasi yang tinggi sehingga mudah disesuaikan dengan kebutuhan pemakai.

\subsection{Analytical Hierarchy Process}

Metode Analytical Hierarchy Process (AHP) mampu membagi masalah yang kompleks dan tidak terstruktur ke dalam komponen-komponen, mengaturnya ke dalam suatu bentuk hierarki, serta memberikan nilai numerik sebagai pengganti subjektivitas manusia dalam melakukan perbandingan 
relatif sehingga menghasilkan suatu sintesa yang menetapkan urutan dan nilai prioritas dari komponenkomponen tersebut [6]. AHP memiliki beberapa kelebihan diantara metode-metode pengambilan keputusan lainnya, antara lain hierarki struktur yang jelas sampai subkriteria terdalam, memperhitungkan validitas sampai batas toleransi inkonsistensi berbagai kriteria dan alternatif yang ada, dan memperhitungkan daya tahan luaran [7].

Adapun prinsip dasar dari AHP adalah sebagai berikut [8]:

a. Menyusun hierarki dimana permasalahan yang akan diselesaikan dipecah menjadi unsur-unsur pembentuknya, yakni kriteria dan alternatif, lalu dibentuk dalam susunan hierarki.

b. Melakukan penilaian kriteria dan alternatif dengan membentuk tabel perbandingan berpasangan (pairwise comparison).

\subsection{Simple Additive Weighting}

Metode Simple Additive Weighting (SAW) dikenal juga sebagai metode penjumlahan terbobot. Pada metode SAW dibutuhkan proses normalisasi matriks keputusan ke suatu bentuk skala yang dapat diperbandingkan dengan semua alternatif yang ada. Terdapat dua jenis kriteria yang dikenal dalam metode SAW, yaitu cost (mengutamakan nilai terendah dalam acuan pemilihan) dan benefit (mengutamakan nilai tertinggi dalam acuan pemilihan) [9].

Sebagaimana yang dijelaskan dalam [10], langkah-langkah SAW sebagai berikut:

a. Menentukan kriteria, $C$, yang dijadikan acuan pengambilan keputusan.

b. Menentukan rating kecocokan tiap alternatif pada kriteria yang ada.

c. Membuat matriks keputusan ternormalisasi, $R$, berdasarkan kriteria $C$, dengan rumus (1)

$$
R_{i j}=\left\{\begin{array}{c}
\frac{x_{i j}}{\max x_{i j}}, j i k a j \text { atribut keuntungan (benefit) } \\
\frac{\min x_{i j}}{x_{i j}}, j i k a j \text { atribut biaya }(\text { cost })
\end{array}\right.
$$

dimana $R_{i j}$ adalah rating kinerja ternormalisasi dan $x_{i j}$ adalah nilai pada baris $i$ kolom $j$ dari matriks.

d. Nilai preferensi akhir diperoleh dengan rumus (2) berikut

$$
V_{i}=\sum_{j=1}^{n} W_{j} R_{i j}
$$

dimana $V_{i}$ adalah nilai akhir dari alternatif, $W_{j}$ adalah bobot yang telah ditentukan, dan $R_{i j}$ adalah rating kinerja ternormalisasi.

\subsection{USE Questionnaire}

USE Questionnaire merupakan singkatan dari Usefulness, Satisfaction, dan Ease of Use. Penggunaan Quetionnaire merupakan salah satu cara untuk mengukur usability aplikasi[11]. Usefulness merupakan kegunaan dari Sistem Pendukung Keputusan yang dibangun, satisfaction merupakan tingkat kepuasan user terhadap Sistem Pendukung Keputusan yang dibangun, dan ease of use merupakan tingkat kemudahan Sistem Pendukung Keputusan bagi user. Parameter ease of use memiliki dua faktor pembentuk, yaitu ease of learning dan ease of use [12]. Contoh paket pertanyaan dalam USE Questionnaire adalah sebagai berikut [12].

Tabel 1. Pertanyaan dalam USE Questionnaire

\section{Usefulness}

1. Aplikasi membuat saya lebih efektif

2. Aplikasi membuat saya lebih produktif

3. Aplikasi tersebut berguna

4. Aplikasi memberikan saya kendali lebih terhadap aktivitas dalam hidup saya

5. Aplikasi membuat hal-hal yang saya inginkan dapat tercapai lebih mudah

6. Aplikasi dapat menghemat waktu saya bila digunakan

7. Aplikasi memenuhi kebutuhan saya

8. Aplikasi melakukan apapun yang saya harapkan darinya

9. Aplikasi mudah digunakan

\section{Ease of Use}


10. Aplikasi sederhana untuk dipakai

11. Aplikasi user friendly

12. Aplikasi hanya memerlukan sedikit langkah untuk menyelesaikan apa yang saya ingin lakukan dengannya

13. Aplikasi bersifat fleksibel

14. Menggunakannya tidak memerlukan usaha keras

15. Saya dapat menggunakannya tanpa petunjuk tertulis

16. Saya tidak menyadari adanya ketidakkonsistenan saat menggunakannya

17. Baik pengguna khusus maupun awam akan menyukainya

18. Saya dapat memperbaiki kesalahan saya dengan cepat dan mudah

19. Saya dapat menggunakannya tanpa kendala setiap kali dicoba

\section{Ease of Learning}

20. Saya belajar menggunakannya dengan cepat

21. Saya dengan mudah mengingat cara menggunakannya

22. Mudah untuk mempelajarinya

23. Saya dengan cepat menjadi ahli menggunakannya

\section{Satisfaction}

24. Saya puas dengan aplikasinya

25. Saya akan merekomendasikannya pada teman saya

26. Aplikasi menyenangkan untuk digunakan

27. Aplikasi bekerja dengan cara yang saya inginkan

28. Aplikasinya sangat bagus

29. Saya merasa saya harus memilikinya

30. Aplikasi menggembirakan untuk digunakan

Skala Likert merupakan skala yang kerap digunakan untuk mengukur sikap, pendapat dan persepsi seseorang atau sekelompok orang mengenai suatu fenomena sosial [13].

Tabel 2. Pengukuran Skala Likert

\begin{tabular}{ll}
\hline Jawaban Responden & Poin \\
\hline Sangat-sangat Setuju (SSS) & 7 \\
Sangat Setuju (SS) & 6 \\
Setuju (S) & 5 \\
Ragu-ragu (RR) & 4 \\
Tidak Setuju (TS) & 3 \\
Sangat Tidak Setuju (STS) & 2 \\
Sangat-sangat Tidak Setuju (SSTS) & 1 \\
\hline
\end{tabular}

[14].

Rumus perhitungan skor pengujian usability berdasarkan Skala Likert yang digunakan adalah

$$
\text { skor total }=(S S S \times 7)+(S S \times 6)+(S \times 5)+(R R \times 4)+(T S \times 3)+(S T S \times 2)+(S S T S \times 1)
$$

Hasil data kuesioner lalu dianalisis untuk mendapat skor persentase kelayakan. Rumus untuk menghitung persentase kelayakan sebagai berikut [15].

$$
\text { Persentase }=\frac{\text { skor yang didapatkan }}{\text { skor yang diharapkan }} \times 100 \%
$$


ILKOM Jurnal IImiah Volume 11 Nomor 3 Desember 2019

Terakreditasi peringkat 3 SK. No. 28/E/KPT/2019

\section{Hasil dan Pembahasan}

Hasil implementasi dari rancangan antarmuka sistem pendukung keputusan akan disajikan dalam bentuk potongan gambar aplikasi. Pada tahap pembangunan aplikasi digunakan bahasa scripting PHP.

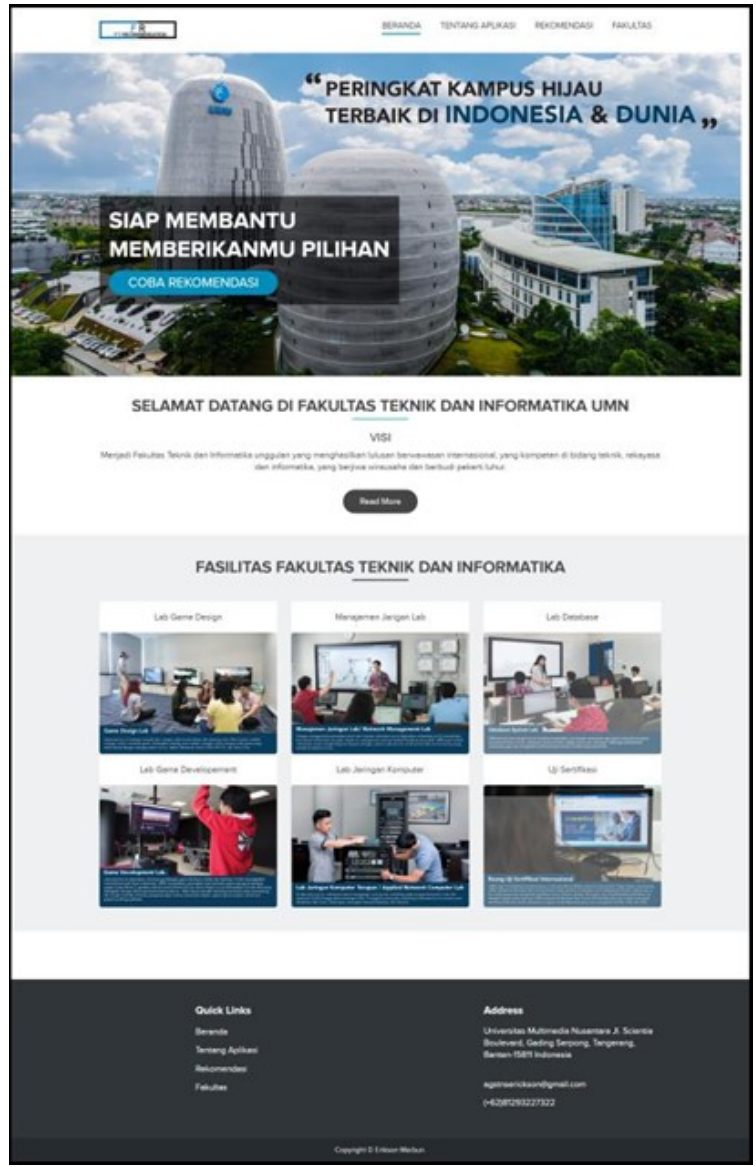

Gambar 1. Halaman Beranda

Gambar 1 adalah hasil implementasi dari halaman menu beranda pada sistem. Pada halaman ini terdapat beberapa pilihan untuk berpindah ke halaman-halaman lainnya dan berisi informasi tentang fasilitas dan fakultas.

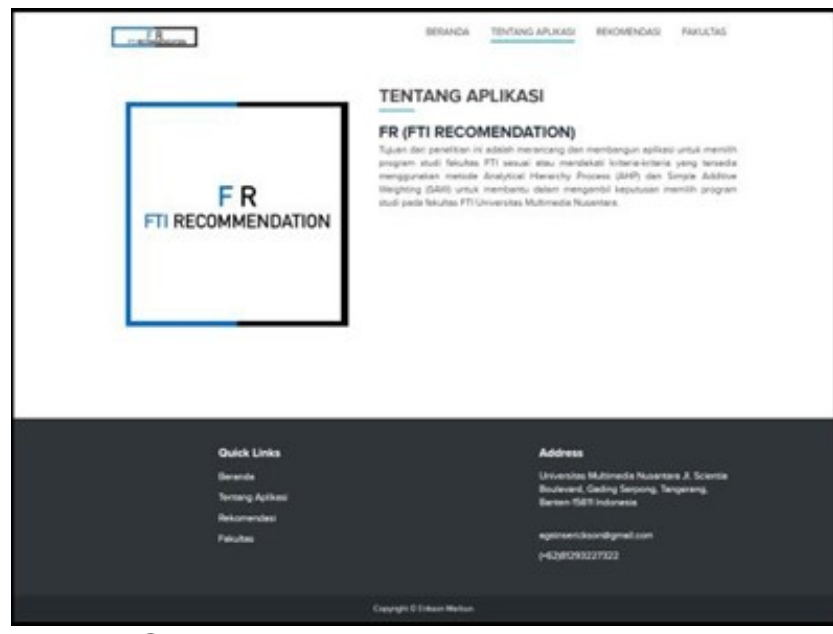

Gambar 2. Halaman Tentang Aplikasi

Gambar 2 adalah hasil implementasi dari halaman tentang aplikasi. Halaman ini menampilkan informasi mengenai aplikasi, logo aplikasi, dan pilihan berpindah halaman ke halaman-halaman lain. 


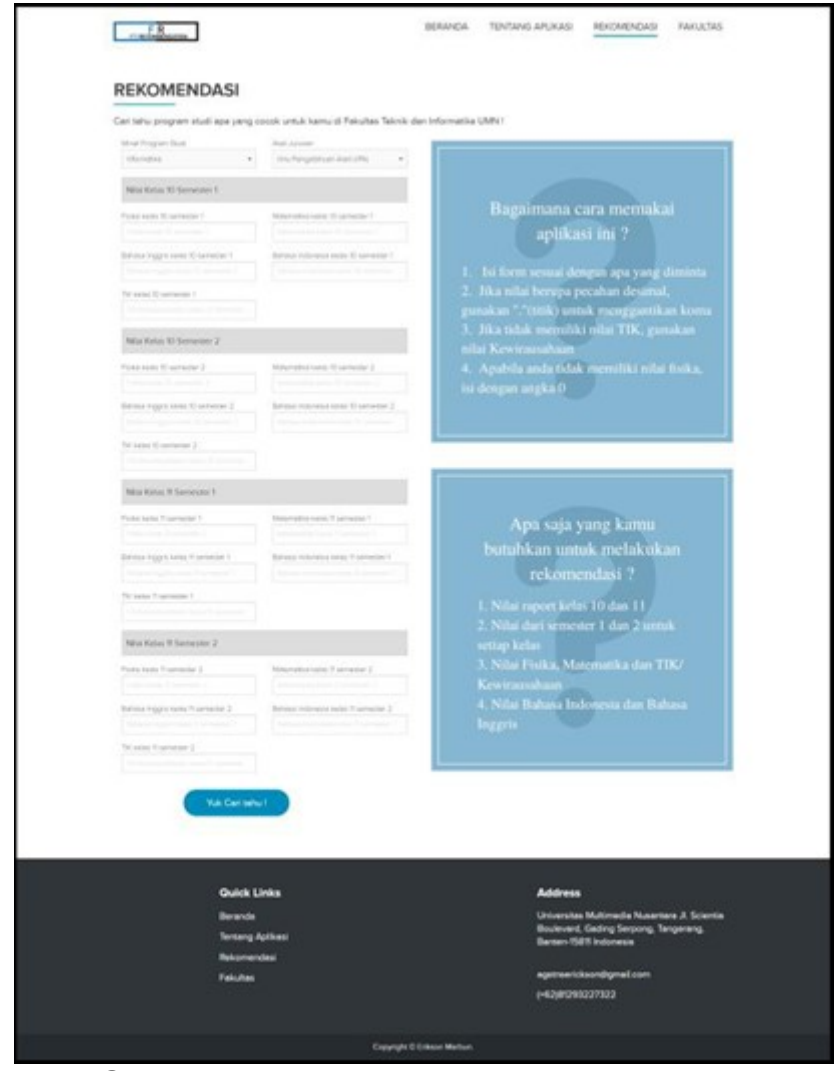

Gambar 3. Halaman Proses Rekomendasi

Gambar 3 adalah hasil implementasi dari halaman proses rekomendasi. Pada halaman ini user dapat melakukan proses rekomendasi dengan cara memasukkan nilai-nilai akademik yang ingin melakukan rekomendasi. Pada saat memasukkan nilai-nilai akademik, aplikasi mengecek apakah nilainilai yang diinput tersebut valid? Karena pada situs tidak akan bisa dimasukkan nilai kurang dari 0 dan lebih dari 100, dan setelah menekan tombol untuk rekomendasi akan berpindah ke halaman hasil rekomendasi.

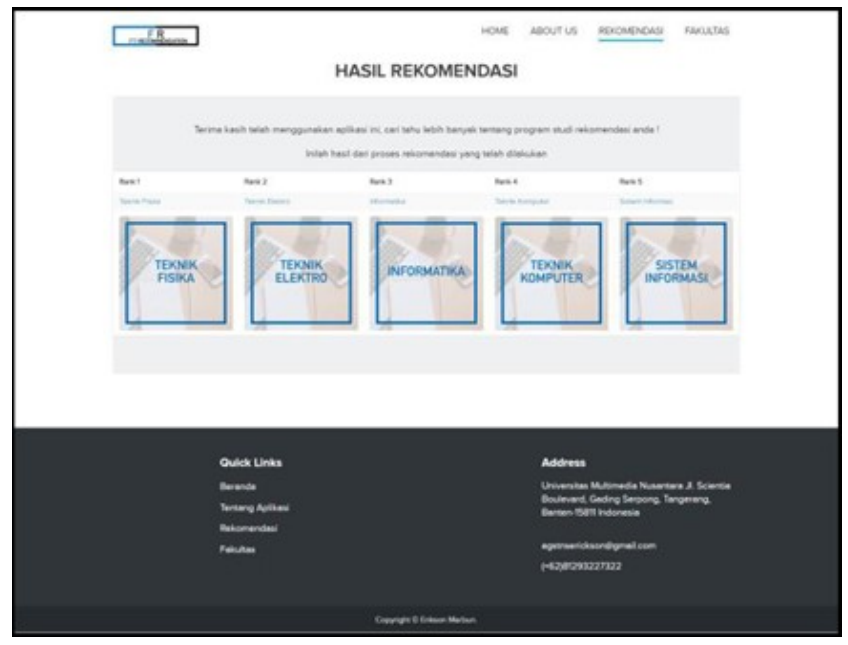

Gambar 4. Halaman Hasil Rekomendasi

Gambar 4 adalah hasil implementasi dari halaman hasil rekomendasi. Halaman hasil rekomendasi akan menampilkan sebuah tabel yang berisi perangkingan program studi yang didapatkan dari proses rekomendasi. Terdapat link untuk berpindah halaman ke halaman detail informasi mengenai program studi yang berada di Fakultas Teknik dan Informatika, apabila di-klik akan berpindah ke halaman detail informasi program studi tersebut. 


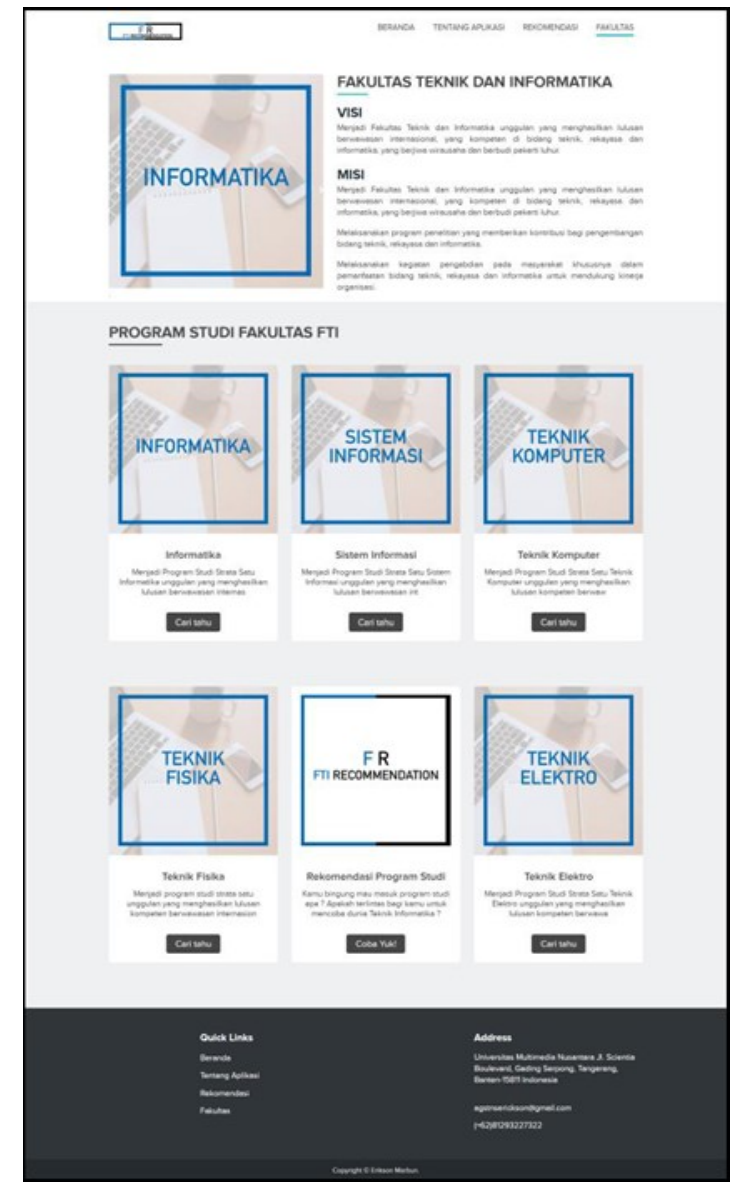

Gambar 5. Halaman Informasi Fakultas

Gambar 5 adalah hasil implementasi dari halaman informasi fakultas. Informasi yang diberikan mengenai program studi yang ada di fakultas, informasi mengenai visi dan misi dari Fakultas, dan pilihan untuk berpindah-pindah ke halaman yang ada di dalam website.

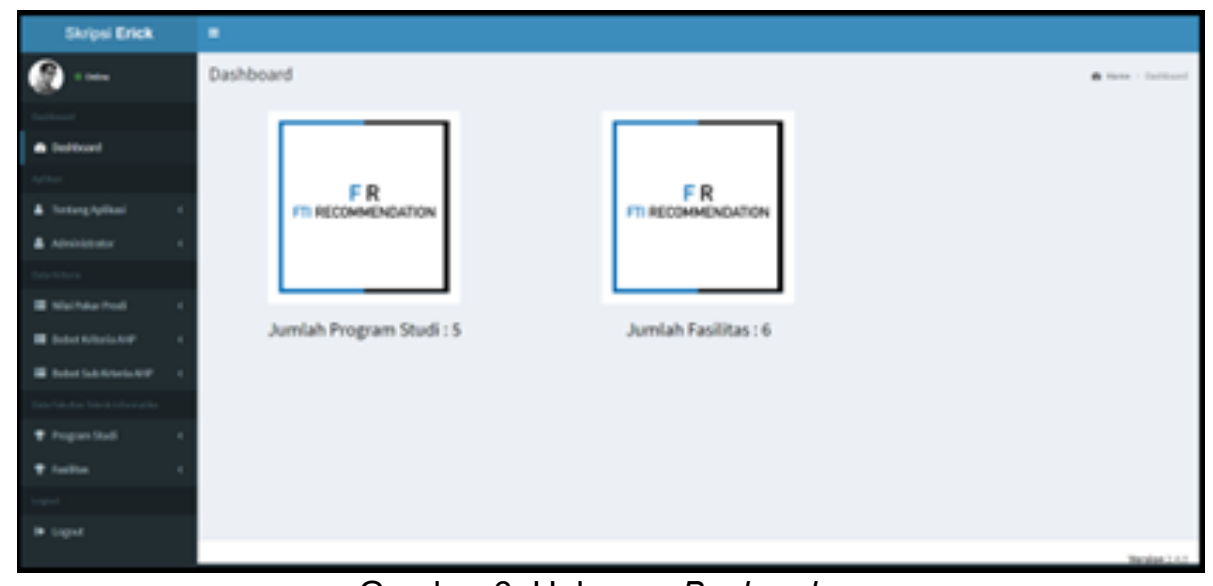

Gambar 6. Halaman Backend

Gambar 6 merupakan implementasi dari halaman Backend yang berisi informasi mengenai banyaknya program studi dan banyaknya fakultas. Pada halaman ini, admin dapat melakukan penambahan, penghapusan, dan pengubahan terhadap data-data yang ada pada situs ' $\mathrm{FTI}$ Recommendation'.

Setelah sistem selesai dirancang dan dibangun, evaluasi sistem dilakukan menggunakan USE Questionnaire untuk mengukur tingkat kepuasan responden yang mencoba aplikasi. Pengujian aplikasi dilakukan kepada 35 responden yang dipilih secara acak, dengan cara menyebarkan link untuk mencoba situs dan sebuah link google form yang berisi USE Questionnaire. 
Evaluasi dilakukan mulai dari tanggal 26 Desember 2018 sampai dengan 1 Januari 2019. Evaluasi dilakukan dengan USE Questionnaire yang disebarkan kepada 35 responden yang dipilih secara acak dari Sekolah Menengah Kejuruan (SMK) dan Sekolah Menengah Atas (SMA). Peserta yang menjadi responden adalah pelajar kelas 3 SMA atau SMK sederajat yang tertarik dengan Fakultas Teknik dan Informatika UMN. Sekolah yang dipilih sebagai responden penelitian adalah sebagai berikut.

1. SMA Strada Thomas Aquino

2. SMK Atisa Dipamkara

3. SMA Tarakanita Citra Raya

4. SMK Bonavita Tangerang

5. SMA Tarsisius Vireta

Tabel 3. Rekapitulasi Hasil Kuesioner

\begin{tabular}{crrrrrrr}
\hline \multirow{2}{*}{ Pertanyaan ke- } & \multicolumn{7}{c}{ Jawaban } \\
\cline { 2 - 8 } & SSTS STS & TSR & S & SS SSS \\
\hline 1 & 0 & 0 & 0 & 1 & 20 & 9 & 5 \\
2 & 0 & 0 & 0 & 0 & 26 & 7 & 2 \\
3 & 0 & 0 & 0 & 1 & 19 & 14 & 1 \\
4 & 0 & 0 & 0 & 1 & 21 & 9 & 4 \\
5 & 0 & 0 & 0 & 3 & 21 & 10 & 1 \\
6 & 0 & 0 & 0 & 5 & 19 & 10 & 1 \\
7 & 0 & 0 & 0 & 4 & 23 & 6 & 2 \\
8 & 0 & 0 & 0 & 3 & 22 & 7 & 3 \\
9 & 0 & 0 & 0 & 7 & 21 & 7 & 0 \\
10 & 0 & 0 & 0 & 3 & 18 & 12 & 2 \\
11 & 0 & 0 & 0 & 3 & 18 & 8 & 6 \\
12 & 0 & 0 & 0 & 2 & 17 & 14 & 2 \\
13 & 0 & 0 & 0 & 5 & 22 & 6 & 2 \\
14 & 0 & 0 & 0 & 4 & 23 & 3 & 5 \\
15 & 0 & 0 & 0 & 2 & 20 & 9 & 4 \\
16 & 0 & 0 & 0 & 6 & 20 & 5 & 4 \\
17 & 0 & 0 & 2 & 4 & 19 & 6 & 4 \\
18 & 0 & 0 & 0 & 6 & 18 & 5 & 6 \\
19 & 0 & 0 & 0 & 3 & 25 & 3 & 4 \\
20 & 0 & 0 & 0 & 4 & 15 & 13 & 3 \\
21 & 0 & 0 & 0 & 4 & 16 & 12 & 3 \\
22 & 0 & 0 & 0 & 4 & 16 & 12 & 3 \\
23 & 0 & 0 & 1 & 2 & 18 & 13 & 1 \\
24 & 0 & 0 & 0 & 2 & 20 & 10 & 3 \\
25 & 0 & 0 & 0 & 1 & 24 & 9 & 1 \\
26 & 0 & 0 & 0 & 5 & 19 & 8 & 3 \\
27 & 0 & 0 & 0 & 3 & 17 & 14 & 1 \\
28 & 0 & 0 & 0 & 3 & 21 & 9 & 2 \\
29 & 0 & 0 & 0 & 5 & 22 & 7 & 1 \\
30 & 0 & 0 & 0 & 2 & 25 & 3 & 5 \\
\hline & & & & & &
\end{tabular}

Berdasarkan hasil rekapitulasi kuesioner pada Tabel 3, dilakukan perhitungan hasil skor dengan menggunakan Skala Likert tujuh poin penilaian. Hasil skor kemudian dihitung persentase kelayakannya. Berikut merupakan penjabaran dari perhitungan persentase kelayakan setiap variabel yang disajikan dalam Tabel 4.

Tabel 4. Hasil Evaluasi

\begin{tabular}{lrr}
\hline Aspek & Total Skor & Persentase \\
\hline Usefulness & 1.496 & $78,5 \%$ \\
Ease of Use & 1.977 & $75,5 \%$ \\
Ease of Learning & 750 & $78,78 \%$ \\
Satisfaction & 1.290 & $77,43 \%$ \\
Overall & 5.313 & $77,22 \%$ \\
\hline
\end{tabular}




\section{Kesimpulan dan Saran}

Berdasarkan penelitian yang telah dilakukan dapat disimpulkan bahwa sistem pendukung keputusan 'FTI Recommendation' telah berhasil dirancang dan dibangun menggunakan metode AHP dan SAW. Sistem ini dapat dimanfaatkan untuk melakukan proses rekomendasi program studi yang ada pada Fakultas Teknik dan Informatika dengan menggunakan delapan kriteria yang terdiri dari tiga kriteria dan lima sub kriteria. Sistem telah diuji coba dengan cara membandingkan perhitungan manual dengan perhitungan yang dilakukan oleh sistem dengan hasil yang sama. Pada penelitian ini juga dilakukan pengujian kepuasan pengguna dengan cara menyebarkan USE Questionnaire kepada 35 responden. Berdasarkan hasil evaluasi yang dilakukan, persentase tingkat kepuasan pengguna mencapai $77,22 \%$ yang berarti sudah baik.

Mengacu pada penelitian yang telah dilakukan, saran perbaikan yang dapat diberikan yakni menambah fitur pendaftaran calon mahasiswa yang ingin mencalonkan diri sebagai mahasiswa Universitas Multimedia Nusantara melewati jalur akademik sehingga dapat lebih memudahkan proses penerimaan mahasiswa dan rekomendasi Program Studi yang tepat bagi mahasiswa.

\section{Daftar Pustaka}

[1] Tominanto, "Sistem Pendukung Keputusan dengan Metode Analytical Hierarchy Process (AHP) untuk Penentuan Prestasi Kinerja Dokter pada RSUD Sukoharjo," J. Infokes, vol. 2, no. 1, pp. 1-15, 2012.

[2] Y. W. Sumarlin, E.W., Hansun, S., dan Wiratama, "Rancang Bangun Aplikasi Rekomendasi Film dengan Menggunakan Algoritma Simple Additive Weighting," J. Inform., vol. 10, no. 2, pp. 1244-1250, 2016.

[3] L. Nurhayati and H. Azis, "Perancangan Sistem Pendukung Keputusan Untuk Proses Kenaikan Jabatan Struktural Pada Biro Kepegawaian," pp. 6-7, 2016.

[4] K. Mann, A. Kaur, and M. Sudhera, "Decision Support System for Patient Care," Int. J. Comput. Eng. Res., vol. 2, no. 8, pp. 70-73, 2012.

[5] E. Sofiah and Y. Septiana, "Sistem Pendukung Keputusan Feasibility Study untuk Menilai Kelayakan Sebuah Bisnis," J. Wawasan IIm., vol. 8, no. 1, pp. 1-7, 2017.

[6] I. Kurniati, S. Hansun, and F. Putri, "Employee Enrollment Decision Support System Using Analytical Hierarchy Process and Promethee Methods," ICSES Trans. Data Sci. Eng. Technol., vol. 2, no. 1, pp. 1-8, 2019.

[7] K. Suryadi, Sistem pendukung keputusan: suatu wacana struktural idealisasi dan implementasi konsep pengambilan keputusan. Bandung: Remaja Rosdakarya, 2002.

[8] Y. Petra and S. Hansun, "Rancang Bangun Sistem Rekomendasi Peminatan Fakultas Teknologi Informasi dan Komunikasi dengan Metode Analytical Hierarchy Process," J. Buana Inform., vol. 7, no. 2, pp. 151-158, Jan. 2016.

[9] S. Kusumadewi, S. Hartati, A. Harjoko, and R. Wardoyo, Fuzzy Multi Attribute Decision Making (FUZZY MADM). Yogyakarta: Graha IImu, 2006.

[10] A. Oktavianus and S. Hansun, "Sistem Rekomendasi Lowongan Kerja dengan Glassdoor API dan Metode Simple Additive Weighting," J. Tek. dan IImu Komput., vol. 7, no. 26, pp. 201-211, 2018.

[11] N. Puspitasari, V. N. Vadilla, U. Hairah, H. Azis, M. Wati, and E. Budiman, "Usability Study of Student Academic Portal from a User's Perspective," 2018 2nd East Indones. Conf. Comput. Inf. Technol., pp. 108-113, 2018.

[12] M. Gao, P. Kortum, and F. Oswald, "Psychometric Evaluation of the USE (Usefulness, Satisfaction, and Ease of use) Questionnaire for Reliability and Validity," Proc. Hum. Factors Ergon. Soc. Annu. Meet., vol. 62, no. 1, pp. 1414-1418, Sep. 2018.

[13] G. Improta, A. Perrone, M. A. Russo, and M. Triassi, "Health technology assessment (HTA) of optoelectronic biosensors for oncology by analytic hierarchy process (AHP) and Likert scale," BMC Med. Res. Methodol., vol. 19, no. 1, p. 140, Dec. 2019.

[14] T. A. Ghaffur, "Analisis Kualitas Sistem Informasi Kegiatan Sekolah Berbasis Mobile Web Di Smk Negeri 2 Yogyakarta," Elinvo (Electronics, Informatics, Vocat. Educ., vol. 2, no. 1, p. 94 , Oct. 2017.

[15] T. N. Sari, "Analisis Kualitas Dan Pengembangan Sistem Informasi Akademik Berbasis Web Menggunakan Standard Iso 9126," JIKO (Jurnal Inform. dan Komputer), vol. 1, no. 1, Feb. 2016. 